\title{
Troubled UK biotech firm faces new probe
}

[LONDON] The biotechnology company British Biotech is to be investigated for a second time by the London Stock Exchange following further revelations last week about its handling of data about sensitive clinical trials.

The investigation follows a decision by the US Securities and Exchange Commission to investigate the accuracy of statements about the company's main anticancer drug marimastat. Concern has also been reported about the company's decision to hold back news of difficulties in clinical trials with its other main drug, the pancreatitis therapy Zacutex.

These developments, as well as this month's sacking of Andrew Millar, director of clinical research (see Nature 392, 746: 1998), have seen British Biotech's share price nosedive to less than $\mathfrak{E} 0.50$ from a high of almost $\mathfrak{E 3} .00$ in 1996 , reducing the value of the company from nearly $£ 2$ billion to $£ 330$ million.

The company's shareholders are now waiting for British Biotech to break its silence. Failure to do may strengthen calls for the removal of its founder and chief execu- tive, Keith McCullagh. A statement from the company was expected this week.

The London stock market had previously cleared a move by three British Biotech directors, including McCullagh, to profit from the sale of shares in January 1995. The sale took place less than two weeks before the suspension of trials on batimastat, which was then the company's main anticancer drug. Batimastat was abandoned soon after.

It has now emerged that Millar circulated a memorandum as early as October 1994 calling for a halt to the clinical trials of batimastat following the discovery of sideeffects.

Millar was dismissed two weeks ago for allegedly passing on confidential information to shareholders about the status of clinical trials with the company's latest flagship drugs. He has said that he was concerned that the company was not being open with shareholders about the progress of its drug trials.

The European Medicines Evaluation Agency (EMEA) wrote to British Biotech in May 1997 detailing its objections to an application for marketing approval for
Zacutex filed in February.

It said that apparently positive results from Zacutex trials in the United Kingdom did not provide conclusive evidence that the drug reduced deaths among sufferers of acute pancreatitis.

British Biotech issued a statement on the success of the UK trial result without alluding to EMEA's reservations. The stock market was not informed of EMEA's objections for another nine months.

Millar has said he was aware that positive results from UK clinical trials were not matched by interim results from a parallel and larger - trial in the United States, and that the company's senior officials were made aware of this information as early as November 1996.

Shareholders, who include leading British fund management companies such as Perpetual and Mercury Asset Management, are expected to ask for a special meeting if the company's statement does not answer questions about the investigations, as well as the state of the company's flagship drugs and its overall strategy.

EhsanMasood

\section{Spanish government pledges full funding for Canaries telescope}

[MUNICH] The Spanish government has pledged to fund fully a 10-metre optical telescope in the Canary Islands - the first large-scale research facility Spain has ever approved - even if no international partners are found.

The decision puts an end to widespread fears in Spain that the government's refusal to make a commitment would delay the project for so long that it would no longer be an internationally competitive facility.

The telescope will be built on Roque de los Muchachos on the island of La Palma, one of two sites belonging to the Institute of Astrophysics of the Canaries (IAC). First light is planned for 2002, and the design will be based on the segmented-mirror structure of the Keck telescope in Hawaii.

After years of lobbying from the IAC, the government last year agreed to pay half the telescope's cost of US\$100 million, but only if the other half was first guaranteed by foreign partners.

Although the project had attracted interest from potential partners as distant as China and India, as well as from universities in Italy, Finland and the United States, none is thought to have felt sufficiently confident of the Spanish government's commitment to make their own funding promises.

Approving funding for the telescope was the first major decision by the newly created Office of Science and Technology (OST), which is in the office of the prime minister.

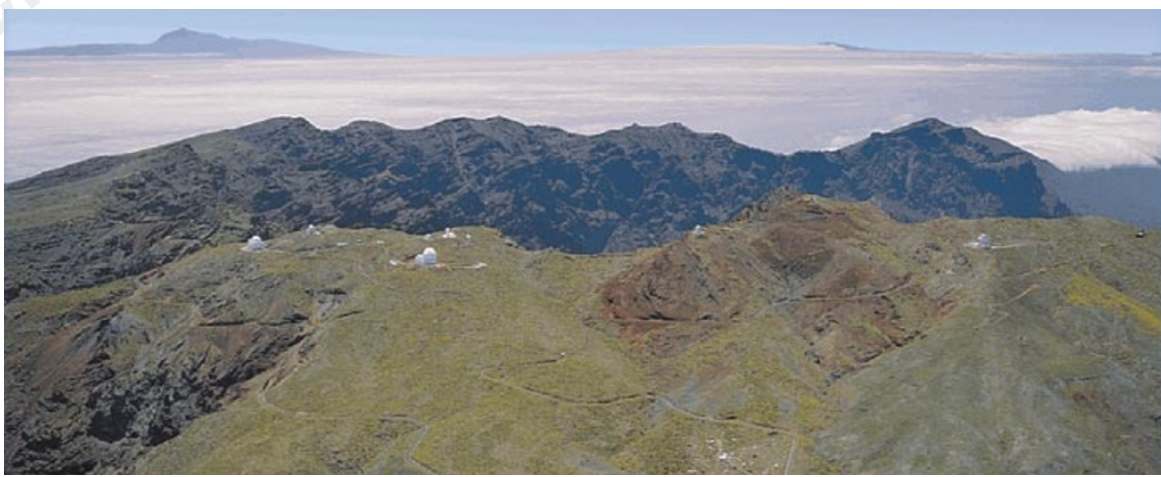

High hopes: the Roque de los Muchados on La Palma where IAC's 10-m optical telescope will be built

"The office has given its definitive approval for the telescope," says Fernando Aldana, head of the OST. "That means that the national government, along with the regional government of the Canary Islands, will bear the whole cost of the project" if it fails to find international partners.

But he says that the IAC should continue to seek such partners to cover up to onethird of the project's costs, "given the scientific and technological contribution foreign experts will bring to it".

Francisco Sanchéz, director of the IAC, says the government's declaration "will allow us to lift the brakes on negotiations" with potential partners. He is confident of being able to sign up partners before the end of the year, giving them time to provide input into the telescope's final design.
Sanchéz says he is keener to bring partners on board for their expertise than for their money. Indeed, he says that there is more interest in the telescope from foreign researchers than the one-third maximum foreign participation the government wants.

For example, the University of Massachusetts is keen to use the telescope to follow up in the infrared spectral range the submillimetre observations made with the Large Millimeter Telescope 50-metre antenna that the university is building in collaboration with Mexico.

Viewing time offered to partners on the new telescope will be proportional to their financial contribution. Partners will also have access to the five per cent observing time on all 20 or so telescopes operating at the IAC's observatory sites. 